\title{
Growth and Quality of Clonal Plantlets of Conilon Coffee (Coffea canephora Pierre ex A. Froehner) Influenced by Types of Cuttings
}

\author{
Abraão Carlos Verdin Filho', Aldo Luiz Mauri' ${ }^{1}$ Paulo Sérgio Volpi ${ }^{1}$, \\ Aymbiré Francisco Almeida da Fonseca², Romário Gava Ferrão, \\ Maria Amélia Gava Ferrão², Wagner Nunes Rodrigues³, Saul de Andrade Júnior4, \\ Tafarel Victor Colodetti ${ }^{3}$ \\ ${ }^{1}$ Instituto Capixaba de Pesquisa Assistência Técnica e Extensão Rural (Incaper), Marilândia, Brazil \\ ${ }^{2}$ Empresa Brasileira de Pesquisa Agropecuária (Embrapa Café), Brasília, Brazil \\ ${ }^{3}$ Centro de Ciências Agrárias, Universidade Federal do Espírito Santo (CCA-UFES), Alegre, Brazil \\ ${ }^{4}$ Escola Estadual Rural de Colatina (EECOR), Colatina, Brazil \\ Email: wagnernunes@outlook.com
}

Received 6 May 2014; revised 5 June 2014; accepted 23 June 2014

Copyright (C) 2014 by authors and Scientific Research Publishing Inc.

This work is licensed under the Creative Commons Attribution International License (CC BY). http://creativecommons.org/licenses/by/4.0/

(c) (i) Open Access

\section{Abstract}

To achieve high crop yield in agriculture, the production of plantlets of superior quality is one of the basic prerequisites. For conilon coffee, the current recommendation in the production of clonal plantlets through vegetative propagation is to use diagonal cuttings, in bevel form. However, there are indications that other types of cutting have been successfully used to produce plantlets. In this context, this experiment was conducted with the objective of studying the development of plantlets of conilon coffee obtained by different types of cuttings. The experiment was conducted in a greenhouse. The cuttings were obtained from the middle portion of orthotropic stems of standardized plants. The experiment followed a split plot in time design, with three types of cuttings (bevel, sharp bevel and straight) and two times of evaluation, with four repetitions. At 30 and 120 days after planting, plantlets were collected and evaluated. The results show the increase occurred in the variables due to the straight cut when compared to the others, except for stem diameter. Emphasizing in this context, the straight cut promoted an increase in seedling height, production of biomass and in the Dickson's quality index when compared to cuttings in bevel and sharp bevel.

\section{Keywords}

Coffea canephora, Asexual Propagation, Vegetative Propagation, Multiplication 


\section{Introduction}

The conilon coffee (Coffea canephora Pierre ex A. Froehner) is originated from tropical rainforests, in low altitudes, extending from the west coast to the central region of the African continent, therefore, this species presents broad adaptation to high temperatures and climatic conditions of lowland tropical regions [1]-[3].

This species has reproduction by outcrossing, due to its gametophytic self-incompatibility, which prevents self-pollination and breeding between plants that have the same genetic constitution in the gametes [4]. Consequently, natural populations of this species, as well as those propagated from seeds (even if collected in just one matrix plant), are characterized by a high frequency of heterozygosity, which results in great genetic variability among populations of these plants.

Due to this natural mechanism, crops of conilon coffee propagated through seeds are often heterogeneous for many agronomic characteristics, such as: plant height; vegetative vigor; timing and uniformity of fruit ripening; shape, size and weight of grains; susceptibility to pests and diseases; drought tolerance; and productive potential [5]-[7].

In this context, the asexual propagation becomes a viable alternative to overcome these characteristics. Among the forms of vegetative propagation, the micropropagation is a fast and efficient technique that can be used to multiply plants of coffee, however, it has high cost relatively to other multiplication techniques, since it demands specialized laboratories, expensive consumables and trained workers [8].

The most commonly used technique in conilon coffee is using cuttings of orthotropic stems, presenting rooting percentage between $95 \%$ and $100 \%$ [9]. This technique of plant propagation enables the maintenance of the genetic characteristics of parental plants, ensuring higher uniformity of the crops [10] and allowing the standardization with higher been field, larger grain size, uniformity of ripening, better beverage quality, among others desirable characteristics [11].

To produce plantlets of high genetic and phytosanitary quality is a basic prerequisite to form crops with potential to achieve high yields, allowing a higher efficiency of use of the area and resulting in a more competitive and sustainable agriculture.

The current recommendation for the production of clonal plantlets of conilon coffee by asexual propagation follows the methodology described by [12], using cuttings from orthotropic stems, with bevel cut approximately $3 \mathrm{~cm}$ below the insertion of the pair of leaves.

However, there is evidence suggesting that other types of cuts can be successfully used to produce plantlets, promoting gains in the growth rate of seedling, especially in relation to the root system.

In this context, this study was conducted with the objective of evaluating the growth and quality of clonal plantlets of conilon coffee obtained with different types of cuttings.

\section{Material and Methods}

The experiment was conducted under controlled conditions, in nursery specialized in producing clonal plants of conilon coffee, located in the municipality of Colatina, northern state of Espírito Santo.

The stems were obtained from adult coffee plants (Coffea canephora Pierre ex A. Froehner), genotype 12 from the clonal cultivar "VitóriaIncaper 8142", grown in clonal garden conduced with arching to stimulate sprouting. The plants were standardized regarding nutritional and phytosanitary aspects. The branches were cut from the middle section of the stems, discarding both ends (apex and base).

The experiment followed a split plot in time scheme, with three types of cutting and two evaluation periods (30 days and 120 days of growth in nursery), in a completely randomized design, with four repetitions and experimental plots composed of 10 plantlets.

All the cuttings were prepared following the current recommendation for asexual propagation in conilon coffee [12], with differentiation only in the lower cutting to follow the cutting types being studied: bevel, sharp bevel (bevel 2) and straight (Figure 1).

The cuttings of each type were standardized by selecting only those that had $4-6 \mathrm{~cm}$ of length to conduct the experiment. The cuttings were inserted in tubes of $280 \mathrm{~mL}$, filled with prepared substrate, properly fertilized for coffee plantlets [13].

The nutrition, irrigation and pest management were made in accordance with current recommendations for seedling production of conilon coffee [12].

The plantlets formed by each type of cutting were evaluated at 30 and 120 days after planting. The plant height was determined with graduated ruler (precision: $0.1 \mathrm{~cm}$ ), from the substrate level to the apex of the stem. 


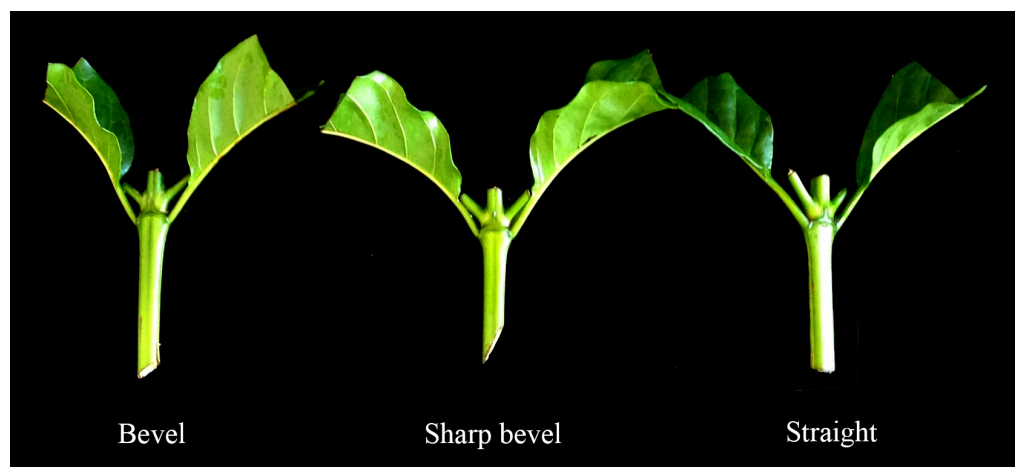

Figure 1. Types of cuttings evaluated: bevel, sharp bevel (bevel 2) and straight.

The stem diameter was measured with digital caliper (precision: $0.01 \mathrm{~mm}$ ).

The plantlets were collected and separated from the substrate by washing. Each plant compartment (roots, stems and leaves) was separated and placed in paper bags, which were taken to laboratory oven, with forced air circulation at $60^{\circ} \mathrm{C}$, until constant weight. After drying, the dry matter was determinate in electronic scale $(0.001$ $\mathrm{g}$ of precision).

The quality of plantlets was calculated by the method proposed by [14], using the Equation (1):

$$
D Q I=\frac{T D M}{\frac{P H}{S D}+\frac{D M_{A P}}{D M_{R S}}}
$$

where:

$D Q I$ : Dickson's quality index;

TDM: total dry matter (g);

$P H$ : plant height (cm);

$S D$ : stem diameter (mm);

$D M_{A P}$ : dry matter of aerial part (g);

$D M_{R S}$ : dry matter of root system (g).

The collected data were subjected to analysis of variance and, in the presence of significant effect of the treatments; the means were compared using the Tukey test (5\% probability). Data analysis was performed using the statistical software GENES [15].

\section{Results and Discussion}

There were significant interactions between the factors for all variables studied in the experiment; therefore, the analyses proceeded to unfold the effects of types of cuttings in relation to the time of evaluation.

The comparison between the means obtained in each period is presented in Table 1. With the exception of stem diameter, it was observed significant growth of the plantlets during the evaluation period, with increase in height and biomass accumulation, resulting in a proportional increase on the quality (Dickson's quality index) to the extent that they approached the ideal time for planting at field.

Figure 2 presents the means obtained at 30 and 120 days for each type of cutting. At 30 days, there was no great difference between the means for most of the characteristics; however, at 120 days was already possible to see further development of the plantlets with straight cutting.

Plant height was similar at 30 days, indicating that the initial growth of the plantlets was homogeneous regardless of the type of cutting. However, the plantlets produced with straight cutting had faster growth than the others types did, presenting higher means for plant height at 120 days (Figure 2(A)).

The growth in stem thickness had no difference between the types of cutting, as the variation between stem diameters of plantlets was insignificant (Figure 2(B)).

The leafiness had already showed differences at 30 days. The bevel cutting provided greater speed and growth of new leaves, while the sharp bevel cutting slowed their development. This initial difference in development of leaves was maintained over time; to 120 days, the plantlets originated from bevel cuttings continued to show more dry matter in the leaves than plantlets with sharp bevel. However, plantlets with straight cutting accumulated 
Table 1. Growth and quality of plantlets of conilon coffee at 30 and 120 days, for each type of cuttings.

\begin{tabular}{ccccccccc}
\hline $\begin{array}{c}\text { Cuttings } \\
\text { type }\end{array}$ & Days & $\begin{array}{c}\text { Plant height } \\
(\mathrm{cm})\end{array}$ & $\begin{array}{c}\text { Stem diameter } \\
(\mathrm{mm})\end{array}$ & $\begin{array}{c}\text { Dry matter } \\
\text { of leaves }(\mathrm{g})\end{array}$ & $\begin{array}{c}\text { Dry matter } \\
\text { of stems }(\mathrm{g})\end{array}$ & $\begin{array}{c}\text { Dry matter } \\
\text { of roots }(\mathrm{g})\end{array}$ & $\begin{array}{c}\text { Total dry } \\
\text { matter }(\mathrm{g})\end{array}$ & $\begin{array}{c}\text { Dickson’s } \\
\text { quality index }\end{array}$ \\
\hline Bevel & 30 & $12.2 \mathrm{~b}$ & $3.3 \mathrm{a}$ & $1.2 \mathrm{~b}$ & $0.8 \mathrm{~b}$ & $0.6 \mathrm{~b}$ & $2.6 \mathrm{~b}$ & $0.4 \mathrm{~b}$ \\
Bevel & 120 & $18.5 \mathrm{a}$ & $3.5 \mathrm{a}$ & $2.0 \mathrm{a}$ & $1.4 \mathrm{a}$ & $1.2 \mathrm{a}$ & $4.5 \mathrm{a}$ & $0.6 \mathrm{a}$ \\
Bevel 2 & 30 & $12.0 \mathrm{~b}$ & $3.4 \mathrm{a}$ & $0.8 \mathrm{~b}$ & $0.8 \mathrm{~b}$ & $0.6 \mathrm{~b}$ & $2.2 \mathrm{~b}$ & $0.3 \mathrm{~b}$ \\
Bevel 2 & 120 & $17.5 \mathrm{a}$ & $3.6 \mathrm{a}$ & $1.6 \mathrm{a}$ & $1.4 \mathrm{a}$ & $1.1 \mathrm{a}$ & $4.0 \mathrm{a}$ & $0.5 \mathrm{a}$ \\
Straight & 30 & $12.9 \mathrm{~b}$ & $3.6 \mathrm{a}$ & $1.0 \mathrm{~b}$ & $1.0 \mathrm{~b}$ & $0.7 \mathrm{~b}$ & $2.6 \mathrm{~b}$ & $0.4 \mathrm{~b}$ \\
Straight & 120 & $21.1 \mathrm{a}$ & $3.9 \mathrm{a}$ & $2.9 \mathrm{a}$ & $2.0 \mathrm{a}$ & $1.5 \mathrm{a}$ & $6.4 \mathrm{a}$ & $0.7 \mathrm{a}$ \\
\hline
\end{tabular}

Means followed by the same letter, within each type of cutting, do not differ by the Tukey test, at 5\% of probability.
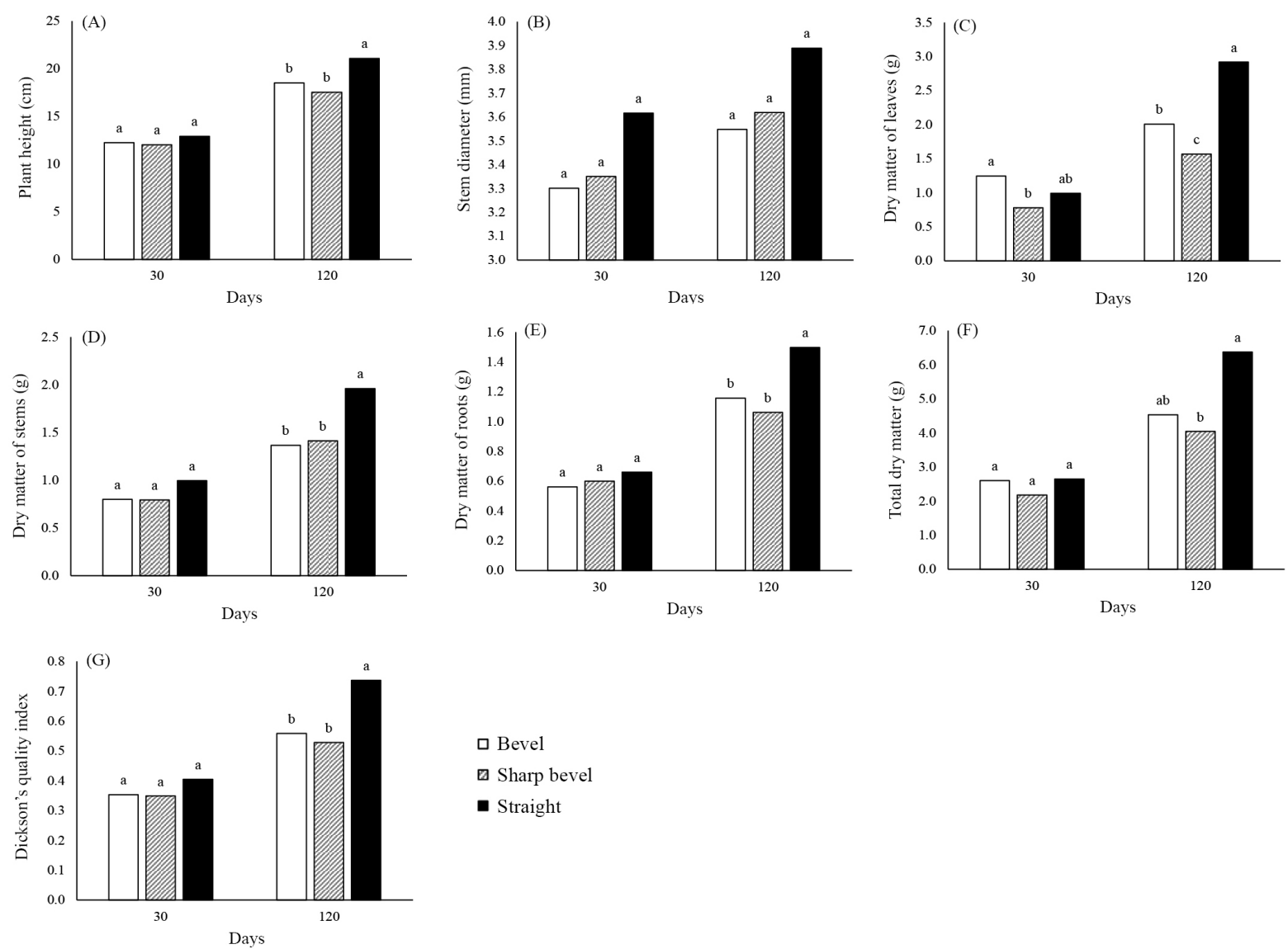

Figure 2. Plant height (A), stem diameter (B); dry matter accumulated of leaves (C); stems (D); roots (E) and total (F); and Dickson's quality index $(\mathrm{G})$ of plantlets of conilon coffee produced with different types of cutting, at 30 and 120 days (Means followed by the same letter do not differ by the Tukey test at $5 \%$ of probability.

more biomass in leaves, surpassing any of the others types of cutting at 120 days (Figure 2(C)).

The accumulation of dry matter in stems and roots showed similar behavior. At 30 days, there was no differentiation between types of cutting; however, at 120 days, the plantlets with straight cutting began to differentiate from the others, presenting higher biomass accumulation in these plant compartments (Figure 2(D) and Figure 2(E)).

After collecting and washing the plantlets, it was observed that the emission of roots was uniform over the area exposed by the cutting when the straight cutting was used. The cuttings in bevel form appears to drive the growth of root to localized points, with a greater growth of the root in the apex of the cut region in detriment of the development of a greater number of roots along the exposed surface (Figure 3). 


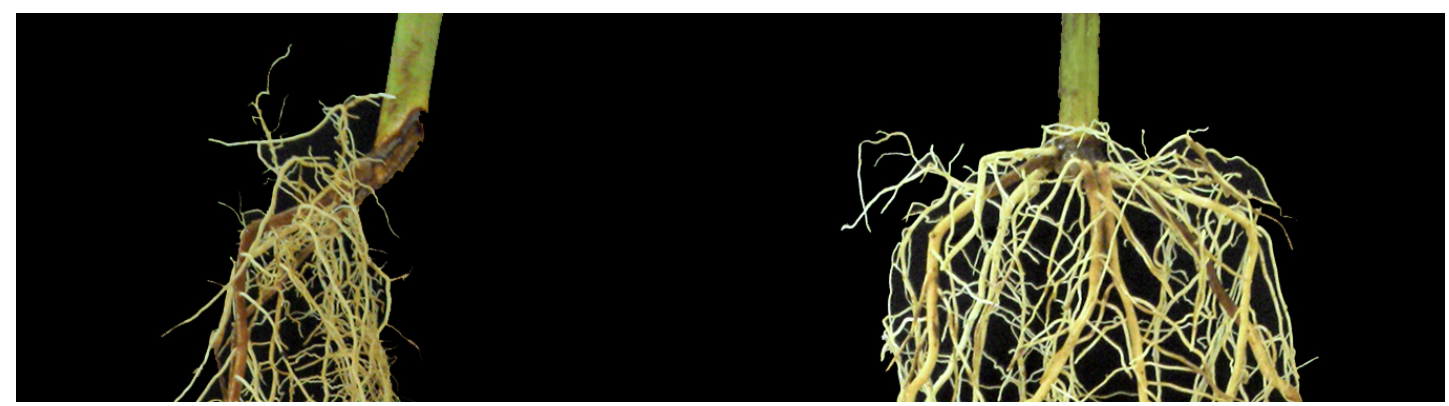

Figure 3. Root development in plantlets of conilon coffee produced with bevel (left) and straight (right) cuttings.

As result of the variables discussed previously, the total dry matter produced by the plants was similar at 30 days; but after 120 days, it was possible to note the superiority of dry matter accumulation of plantlets produced with straight cutting (Figure 2(F)).

The quality of the plantlets at 120 days was favored with use of straight cutting, this is the type of cutting that promoted the production of plantlets of higher Dickson's quality index (Figure 2(G)). This quality index has been cited as a promising criterion to morphologically evaluate many plant species, especially for considering the vigor and pattern of allocation of biomass as parameters to determinate it [16] [17].

The significant differentiation between the types of cutting at 120 days shows that straight cutting had superior growth compared to the others in all the studied variables, except for the stem diameter. Emphasizing in this context, the straight cutting promoted gains in many aspects when compared to cutting in bevel and sharp bevel. It is reported $14.0 \%$ and $20.5 \%$ gain on plant height; $45.0 \%$ and $81.2 \%$ on dry matter of leaves; $42.8 \%$ and $42.8 \%$ on dry matter of stems; $25.0 \%$ and $36.3 \%$ in dry matter of roots; $42.2 \%$ and $60.0 \%$ on total dry matter; $16.6 \%$ and $40.0 \%$ at seedling quality, respectively.

\section{Conclusion}

The different types of cutting have effect over the growth and quality of plantlets of conilon coffee. The use of straight cutting promotes the formation of plantlets with higher growth and better quality.

\section{References}

[1] Charrier, A. and Berthaud, J. (1985) Botanical Classification of Coffee. In: Clifforf, M.N. and Willson, K.C., Eds., Coffee: Botany, Biochemistry, and Production of Beans and Beverage, Croom Herm, Westport, London, 13-47.

[2] Bragança, S.M. (2005) Growth and Accumulation of Nutrients for the Coffee Plant Conilon (Coffea canephora Pierre). D.Sc. Thesis, Universidade Federal de Viçosa, Viçosa.

[3] Davis, A.P., Govaerts, R., Bridson, D.M. and Stoffelen, P. (2006) An Annotated Taxonomic Conspectus of the Genus Coffea (Rubiaceae). Botanical Journal of the Linnean Society, 152, 465-512. http://dx.doi.org/10.1111/j.1095-8339.2006.00584.x

[4] Devreux, M., Vallaeys, G., Pochet, P. and Gilles, A. (1959) Recherchessurl'autosterilité du caféierrobusta (Coffea canephora Pierre). SérieScintifique, 78, 1-44.

[5] Ferrão, R.G., Fonseca, A.F.A., Ferrão, M.A.G., Bragança, S.M., VerdinFilho, A.C. and Volpi, P.S. (2007) Cultivars of Conilon Coffee. In: Ferrão, R.G., Fonseca, A.F.A., Bragança, S.M., Ferrão, M.A.G. and De Muner, L.H., Eds, Coniloncoffee, Incaper, Vitória, 203-225.

[6] Van Der Vossen, H.A.M. (1985) Coffee Selection and Breeding. In: Clifford, M.N. and Wilson, K.C., Eds., Coffee: Botany, Biochemistry and Production of Beans and Beverage, Croom Herm, Westport, London, 48-96.

[7] Carvalho, A., Medina Filho, H.P., Fazuoli, L.C., Guerreiro Filho, O. and Lima, M.N.A. (1991) Genetic Aspects of Coffee. RevistaBrasileira de Genética, 14, 135-183.

[8] Santos, M.R.A. and Ferreira, M.G.R. (2011) Micro Propagation of Conilon Coffee. Embrapa, Rondônia, 2.

[9] Paulino, A.J., Matiello, J.B. and Paulini, A.E. (1985) Production of Plantlets of Conilon Coffee by Cuttings: Technical Instructions about the Coffee Cultivation in Brazil. IBC/GERCA, Rio de Janeiro, 12.

[10] Bragança, S.M., Carvalho, C.H.S., Fonseca, A.F.A. and Ferrão, R.G. (2001) “Encapa 8111”, “Encapa 8121” “Encapa 8131”: Clonal varietiesofconiloncoffee for the Espírito Santo State, Brazil. Pesquisa Agropecuária Brasileira, 36, 765770. http://dx.doi.org/10.1590/S0100-204X2001000500006 
[11] Fonseca, A.F.A., Ferrão R.G., Ferrão, M.A.G., Volpi, P.S., VerdinFilho, A.C. and Fazuoli, L.C. (2008) Cultivars of Robusta Coffee. In: Carvalho, C.H., Ed., Cultivars of Coffee: Origins, Characteristics and Recommendations, Embrapa Café, Brasília, 255-279.

[12] Ferrão, R.G., Fonseca, A.F.A., Ferrão, M.A.G., VerdinFilho, A.C., Volpi, P.S., DeMuner, L.H., Lani, J.A., Prezotti, L.C., Ventura, J.A., Martins, D.S., Mauri, A.L., Marques, E.M.G. and Zucateli, F. (2012) Conilon Coffee: Production Techniques for Improved Cultivars. Incaper, Vitória, 74.

[13] Prezotti, L.C., Gomes J.A., Dadalto, G.G. and Oliveira, J.A. (2007) Guidelines for Recommendation of Liming and Fertilization for Espírito Santo State. SEEA/Incaper/CEDAGRO, Vitória, 305.

[14] Dickson, A., Leaf, A.L. and Hosner, J.F. (1960) Quality Appraisal of White Spruce and White Pine Seedling Stock in Nurseries. Forest Chronicle, 36, 10-13. http://dx.doi.org/10.5558/tfc36010-1

[15] Cruz, C.D. (2013) GENES: A Software Package for Analysis in Experimental Statistics and Quantitative Genetics. Acta Scientiarum: Agronomy, 35, 271-276. http://dx.doi.org/10.4025/actasciagron.v35i3.21251

[16] Johnson, J.D. and Cline, M.L. (1991) Seedling Quality of Southern Pines. In: Duryea, M.L. and Dougherty, P.M., Eds., Forest Regeneration Manual, Klumer Academic, Netherlands, 143-162. http://dx.doi.org/10.1007/978-94-011-3800-0_8

[17] Fonseca, E.P., Valéri, S.V., Miglioranza, E., Fonseca, N.A.N. and Couto, A. (2002) Target Plantlets of Trema micrantha (L.) Blume Grown under Different Periods of Shading. Revista Árvore, 26, 515-523. 
Scientific Research Publishing (SCIRP) is one of the largest Open Access journal publishers. It is currently publishing more than 200 open access, online, peer-reviewed journals covering a wide range of academic disciplines. SCIRP serves the worldwide academic communities and contributes to the progress and application of science with its publication.

Other selected journals from SCIRP are listed as below. Submit your manuscript to us via either submit@scirp.org or Online Submission Portal.
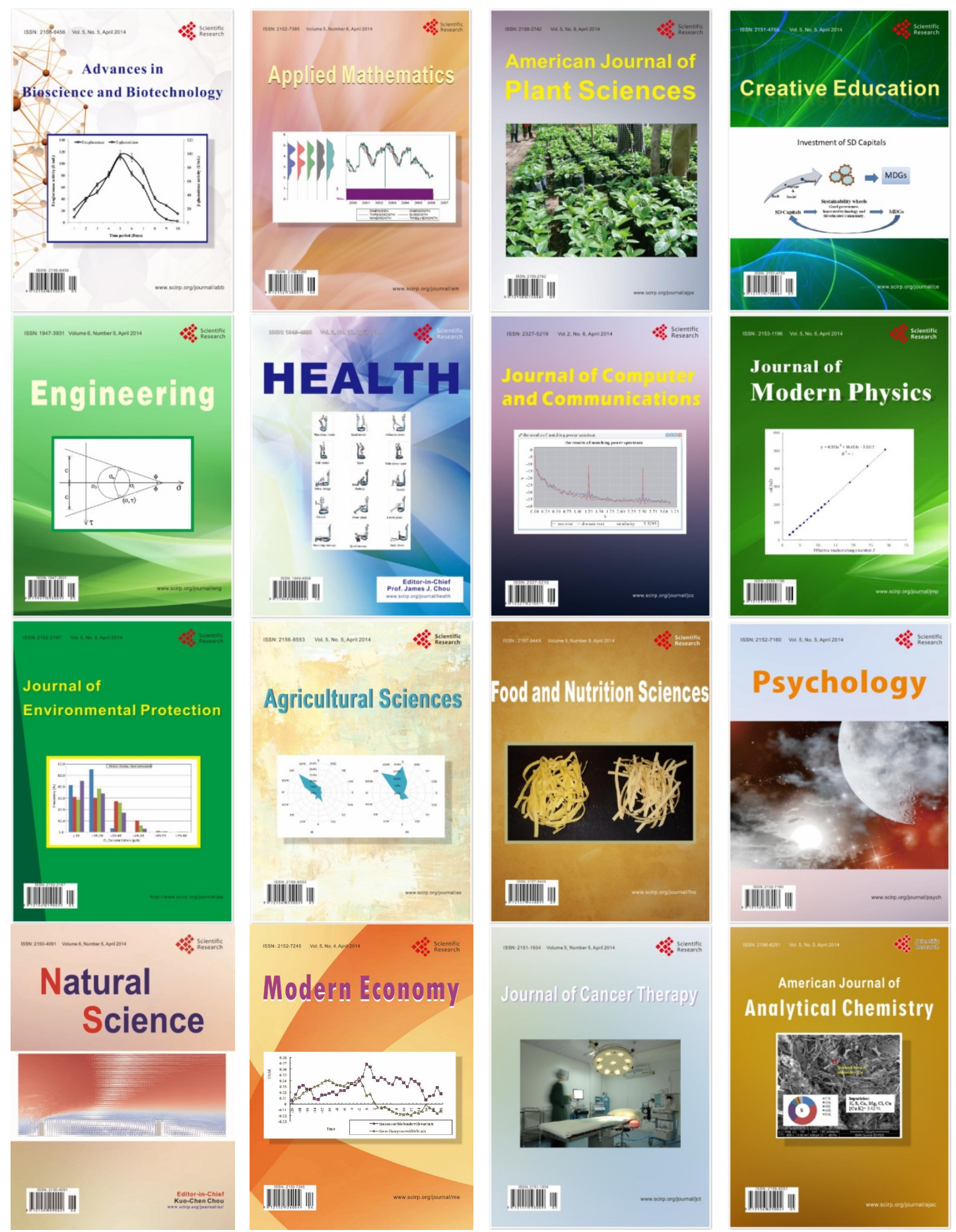